\title{
Corporate
}

\section{competitiveness in Latin America and the Caribbean}

Michael Mortimore

Chief, Unit on Investment and Corporate Strategies, Division of Production,

Productivity and

Management, ECLAC

Wilson Peres

Chief, Industrial and

Technological

Development Unit,

Division of Production,

Productivity and

Management, ECLAC
This article looks at the evolution of international competitiveness in the countries of Latin America and the Caribbean in the 1990s, focusing on the microeconomic and sectoral aspects. It evaluates the competitive performance of the region's countries, contrasting it with that of their main competitors in the developing world; it analyses the corporate actors involved, including the subsidiaries of transnational enterprises and large locally owned firms; and it sets forth some political considerations. Although progress has been made with competitiveness in the region, this has been largely confined to just a few countries, sectors and firms. Differences in the institutional conditions under which the countries participate in the world economy, and in their comparative cost advantages, have resulted in the emergence of two distinct trading styles. In Mexico and the Caribbean Basin, exports of manufactures assembled for the United States market predominate. In South America, on the other hand, natural resource production and processing activities prevail, with more technologically advanced manufactures having some presence in intraregional trade, especially within Mercosur. Both sectoral specializations present opportunities and problems. Improvements in the competitiveness of large companies (whether transnational or locally owned) have enhanced their efficiency. But the same is not true of other agents in the countries' economies, whose production structures have thus become more polarized. This polarization needs to be dealt with by policy initiatives. Four areas of action are important: increasing efforts to attract selected foreign direct investment (FDI); strengthening the links between leading companies and the other firms in each country; supporting the creation of global knowledge networks; and enhancing the ability of domestic companies to enter into joint ventures and strategic alliances with their global competitors. 


\section{I}

\section{Introduction}

For more than a decade, the countries of Latin America and the Caribbean have been proceeding with structural reforms aimed at improving production efficiency, promoting growth and generating employment in the region. ${ }^{1}$ The new economic model that the reforms put in place to achieve these objectives entails far-reaching involvement in the world economy. Participation in what are growing and increasingly integrated international flows of goods, services, technology and capital is seen as a prerequisite for taking advantage of the benefits generated by the removal of restrictions on the operations of economic agents. Within this framework, the State has yielded leadership to private enterprises that operate in much less regulated economies than was the case until just over a decade ago. Openness, privatization and competition are thus the cornerstones of the new model (Reinhardt and Peres, 2000).

Globalization, understood as the movement towards a single world market, has been the result of microeconomic forces generated by the technological revolution now in progress. Lower information handling and transport costs have made it profitable for some industries to carry out production, marketing and research and development activities on a world scale (Turner and Hodges, 1992), and this has increased the importance of economies of scale in those sectors and given the ascendancy to large firms. The homogenization of preferences, technologies and products predicted by Levitt (1983) would appear to be taking place. Public policies of national or local scope are playing a secondary role in this process, since in general they can do no more than check it or slow it down, without changing its direction or effects (Oman, 1994).

The increasing integration of markets worldwide is opening up great opportunities and posing major challenges for developing countries, which may or may not take advantage of the former and take the right steps to deal with the latter (Sunkel and Mortimore, 1997). If the opportunities are to be fully capitalized upon, countries need to participate efficiently in this world market, which can only happen if companies become increasingly competitive (Lall and Mortimore, 2000).

The objective of the present study is to set forth some considerations that will assist in evaluating the competitive efficiency of the Latin American and Caribbean countries in the 1990 s, paying special attention to two aspects: the groups of economic sectors that have been gaining or losing competitiveness and the types of companies (transnational or local, publicsector or private-sector) responsible for this sectoral and national performance. The study is divided into five sections. Following this introduction, section II looks at the way competitiveness has developed in the region's countries by comparison with their main competitors in the developing world, i.e., the more dynamic countries of East and South-East Asia. Section III analyses the companies that are playing the leading role in this process: transnationals operating in the region, and large locally owned firms. Lastly, sections IV and V offer conclusions and policy considerations.
${ }^{1}$ The term "structural reform" is used to refer to the strategies for
change followed by most of the region's countries since the early
1980 s, although important initiatives of this kind were pursued in
the previous decade, for example in Chile. Its basic components
have been trade liberalization, privatization of State enterprises, deregulation of markets and businesses, the opening up and liberalization of domestic financial markets and the capital account, and fiscal reform. Different authors employ terms such as "economic reform" and "structural change" to describe the same phenomenon (Stallings and Peres, 2000). 


\section{II}

\section{The region's place in the international economy in the 1990s}

\section{Competitiveness in the international context}

Transnationalization and the growth of international trade have been central factors in globalization and the progress of developing countries. While the share of international trade in the GDP of the industrialized countries has held steady at about $40 \%$, in developing countries it rose from about $35 \%$ in the early 1980 s to close to $50 \%$ in the late 1990 s. It is in fact developing countries that have capitalized most on international trade opportunities; greater competition among economies is the result of their eagerness to boost trade flows.

During the period from 1985 to 1998 , manufactures (to three digits in the SITC, revision 2) continued on a growth course and increased their export share relative to primary products. In this period, the share of manufactures in the total value of world exports rose from $74 \%$ to $84 \%$, while that of natural resources fell from $23 \%$ to $12 \%$ (CAN 2000). ${ }^{2}$

Table 1 shows in which activities and to what extent the developing countries have taken advantage of manufacturing export opportunities. They have surpassed the industrialized countries in this respect, gaining three percentage points of market share in the period 1985-1998. This progress was due to three types of non-natural resource-based manufactures (high technology content: 16.6 points; medium: 9.1 points; and low: 16 points) and not to natural resource-based manufactures or unprocessed natural resources, as might be expected if a simplistic view were taken of comparative advantages. Also unexpected is the increase in the developed countries' share of the market for natural resources, which rose from $37.8 \%$ in 1985 to $43.2 \%$ in 1998.

A more detailed breakdown of the information, using the CAN 2000 software, shows that in the three

\footnotetext{
2 By CAN 2000 is meant the Competitive Analysis of Nations software, 2000 version, developed by the ECLAC Division of Production, Productivity and Management (for the user manual see LC/R.1258).
}

categories of manufactures in which developing countries have gained market share, four activities are particularly dynamic: electronics, continuous process industries, vehicle manufacturing and wearing apparel. These manufactures are not based on natural resources, and they are concentrated at the high-technology (electronics) and low-technology (apparel) ends; activities involving an intermediate level of technology (vehicle manufacturing and continuous process and engineering industries) have not developed to the same degree.

The developing countries of Asia took advantage of the opportunities open to them in all areas, even natural resource-based manufacturing; they made the greatest progress, however, with non-natural resource-based manufactures, especially those involving high (145\% increase in market share) and intermediate (123\% increase) levels of technology. In particular, while Asia tended to specialize further in high- and medium-technology sectors, Latin America did so in medium- and low-technology sectors.

The increases in market share achieved by Latin America were smaller than those achieved by Asia. In high-technology manufactures, the increase was one percentage point, as compared with over 16 points in the case of Asia. In short, of the almost 13 percentage points represented by the opportunities available in nonnatural resource-based manufacturing, Asia took almost 11 points, while Latin America took less than two points.

Developing countries have thus been given an opportunity to enter the international market, and much of their success has had to do with the dissemination of integrated international production systems (IIPS) (UNCTAD, 1993 and Lall and Mortimore, 2000). Only a few countries, however, have managed to benefit from these systems. To take advantage of international trade opportunities, countries have to incorporate themselves into the strategies of efficiency-seeking transnational enterprises. And not all those that have participated have done so successfully. 
TABLE 1

World market share, by export type, 1985-1998

(Percentages)

\begin{tabular}{|c|c|c|c|c|c|c|c|c|}
\hline \multirow[t]{2}{*}{ Export type } & \multicolumn{2}{|c|}{ Industrial countries } & \multicolumn{2}{|c|}{ Developing countries } & \multicolumn{2}{|c|}{ Developing Asia } & \multicolumn{2}{|c|}{ Latin America } \\
\hline & 1985 & 1998 & 1985 & 1998 & 1985 & 1998 & 1985 & 1998 \\
\hline Natural resources & 37.8 & 43.2 & 62.1 & 56.8 & 29.7 & 27.4 & 12.3 & 13.8 \\
\hline Manufactures based on natural resources & 68.1 & 69.5 & 31.3 & 30.5 & 12.4 & 14.4 & 6.5 & 6.2 \\
\hline Manufactures not based on natural resources & 82.4 & 69.7 & 17.5 & 30.3 & 11.6 & 22.1 & 2.5 & 4.3 \\
\hline Low-technology & 51.5 & 35.5 & 48.5 & 64.5 & 39.1 & 49.8 & 4.0 & 6.7 \\
\hline Medium-technology & 89.4 & 80.3 & 10.6 & 19.7 & 5.2 & 11.6 & 2.4 & 4.5 \\
\hline High-technology & 83.0 & 66.4 & 17.0 & 33.6 & 11.3 & 27.6 & 2.0 & 3.0 \\
\hline Others & 71.1 & 62.2 & 28.9 & 37.7 & 6.4 & 11.0 & 4.1 & 4.1 \\
\hline Total & 68.7 & 65.8 & 31.3 & 34.2 & 16.0 & 21.5 & 5.6 & 5.7 \\
\hline
\end{tabular}

Source: The authors, on the basis of the CAN 2000 software.

TABLE 2

World market share, by groups of countries

(Percentages)

\begin{tabular}{ccccc}
\hline Year & $\begin{array}{c}\text { Latin America } \\
\text { and the Caribbean }\end{array}$ & China & $\begin{array}{c}\text { Hong Kong, Rep. of Korea, } \\
\text { Singapore and Taiwan }\end{array}$ & $\begin{array}{c}\text { Indonesia, Malaysia, } \\
\text { Philippines and Thailand }\end{array}$ \\
\hline 1985 & 5.57 & 1.60 & 5.51 & 2.80 \\
1986 & 5.03 & 1.76 & 6.02 & 2.57 \\
1987 & 4.66 & 1.94 & 6.68 & 2.52 \\
1988 & 2.22 & 7.09 & 2.65 \\
1989 & 4.63 & 2.45 & 6.97 & 2.72 \\
1990 & 4.61 & 2.82 & 6.95 & 3.04 \\
1991 & 4.53 & 3.18 & 6.90 & 3.38 \\
1992 & 4.38 & 3.74 & 7.25 & 3.72 \\
1993 & 4.41 & 4.26 & 7.48 & 4.00 \\
1994 & 4.62 & 4.62 & 7.66 & 4.16 \\
1995 & 4.81 & 4.81 & 7.63 & 4.30 \\
1996 & 5.01 & 5.06 & 7.44 & 4.36 \\
1997 & 5.27 & 5.33 & 7.37 & 4.37 \\
\hline
\end{tabular}

Source: The authors, on the basis of the CAN 2000 software.

There are large differences between Asia and the Latin America and Caribbean region. ${ }^{3}$ Table 2 shows that, in the period 1985-1998, the countries of this region as a whole barely maintained their world market

\footnotetext{
${ }^{3}$ Despite the crisis of the late 1990s, the countries of East Asia have also achieved much better results than Latin America in terms of GDP growth, industrialization and improvements in the competitiveness of manufacturing exports. In Asia, international trade has clearly operated as an engine of economic growth (Lall, 2000). In Latin America, on the other hand, progress with per capita GDP growth, industrialization and manufacturing exports has not been encouraging; by and large, the benefits expected from greater integration into the international market have not materialized (Mortimore, Bonifaz and Duarte de Oliveira, 1997).
}

share, in marked contrast with China and the countries of South-East Asia with a large natural resource base (Indonesia, Malaysia, the Philippines and Thailand). The region also failed to match the results achieved by the countries of East Asia that specialized in manufacturing, whose market share at the beginning of the period was already higher than the region's was in the late 1990s. The contrast is most marked at the beginning of the period, when the region's market share fell by more than a percentage point just as Asia was enjoying strong growth. In the second half of the decade, the pace slowed in Asia, with the exception of China, while Latin America began a gradual climb back to the levels of market share it had held 10 years before. 
TABLE 3

Technological specialization index, 1985-1998

\begin{tabular}{|c|c|c|c|c|c|c|}
\hline Year & China & $\begin{array}{l}\text { Hong Kong, Rep. of Korea, } \\
\text { Singapore and Taiwan }\end{array}$ & $\begin{array}{c}\text { Indonesia, Malaysia, } \\
\text { Philippines and Thailand }\end{array}$ & $\begin{array}{l}\text { Latin } \\
\text { America }\end{array}$ & Mexico & $\begin{array}{l}\text { Mercosur } \\
\text { countries }\end{array}$ \\
\hline 1985 & 0.153 & 0.849 & 0.267 & 0.272 & 0.650 & 0.289 \\
\hline 1986 & 0.173 & 0.858 & 0.269 & 0.297 & 0.765 & 0.309 \\
\hline 1987 & 0.216 & 0.917 & 0.305 & 0.322 & 0.931 & 0.307 \\
\hline 1988 & 0.273 & 0.991 & 0.344 & 0.336 & 1.007 & 0.303 \\
\hline 1989 & 0.320 & 1.054 & 0.394 & 0.336 & 1.060 & 0.285 \\
\hline 1990 & 0.339 & 1.082 & 0.454 & 0.340 & 1.107 & 0.274 \\
\hline 1991 & 0.350 & 1.111 & 0.523 & 0.365 & 1.205 & 0.289 \\
\hline 1992 & 0.360 & 1.154 & 0.603 & 0.402 & 1.336 & 0.308 \\
\hline 1993 & 0.378 & 1.225 & 0.692 & 0.428 & 1.444 & 0.311 \\
\hline 1994 & 0.420 & 1.377 & 0.802 & 0.437 & 1.483 & 0.295 \\
\hline 1995 & 0.461 & 1.492 & 0.895 & 0.447 & 1.518 & 0.280 \\
\hline 1996 & 0.500 & 1.566 & 0.979 & 0.465 & 1.514 & 0.294 \\
\hline 1997 & 0.524 & 1.529 & 1.021 & 0.508 & 1.575 & 0.322 \\
\hline 1998 & 0.534 & 1.508 & 1.048 & 0.526 & 1.582 & 0.343 \\
\hline
\end{tabular}

Source: The authors, on the basis of the CAN 2000 software and the methodology of Alcorta and Peres (1998).

Latin America's world trade performance is technologically inferior to that of East and South-East Asia as well. Table 3 provides information on the dynamic of technological specialization indices (TSIs) for the exports of the region and its main Asian competitors. ${ }^{4}$ Although the TSI of the region virtually doubled between 1985 and 1998, it was still lower than the index values achieved not only by Hong Kong Special Administrative Region, the Republic of Korea, Singapore and Taiwan Province of China, but also by Asian countries with a large natural resource base (Indonesia, Malaysia, the Philippines and Thailand). Furthermore, the dynamic of the region is determined by that of Mexico, a country which has achieved TSI levels similar to or higher than those of East Asia, while the best the countries of Mercosur can show is a modestly upward trend, with levels much lower than those of Asia and Mexico. The region is even lagging well behind China, which still has a low TSI.

\footnotetext{
${ }^{4}$ The TSI is calculated as the ratio between the market share of a country or group of countries in high- and medium-technology sectors and its share in low-technology sectors. Both the absolute levels and the rates of change of TSIs are significant. A value lower (higher) than one indicates that a country's market share in highand medium-technology sectors is higher (lower) than its share in low-technology sectors. A rising (falling) value for the TSI over time indicates a shift towards higher (lower) market shares in highand medium-technology markets. For further details, see Alcorta and Peres (1998).
}

Lastly, the contrast between East Asia and Latin America is also reflected in the ranking of the 10 economies that have most improved their international competitiveness (measured in relation to world imports) for the 50 product groups (down to three digits in the SITC, revision 2) that were most dynamic in world trade during 1985-1998. The 10 economies, in descending order, are China, Mexico, Singapore, Malaysia, Spain, Taiwan, Thailand, Ireland, the Republic of Korea and the Philippines. In other words, seven Asian economies, two European ones and one Latin American one. These are the economies that have managed to take greatest advantage of the shift in trade patterns and the international economy towards a single world market. With the exception of the Republic of Korea and Taiwan, whose trading success has been driven by local companies, the progress these economies have achieved with trade has been directly linked to the IIPS of transnational companies. Furthermore, six of the 10 also feature among the economies with the fastest per capita GDP growth, which would seem to indicate that their international trading success has served to stimulate and develop their economies. Neither Mexico nor Spain achieved any remarkable increase in per capita GDP over the same period, however, which suggests that for lasting success something more than the conquest of markets is required.

All the results described in this section indicate that the region is not very competitive, has made little progress in increasing its world market share and the technology-intensiveness of its exports, and has shown 
only a moderate ability to adjust its export profile to the changing dynamic of international trade. The results also indicate that, within Latin America and the Caribbean, Mexico and the Caribbean Basin need to be distinguished from South America.

\section{Subregional developments}

Of the 25 Latin American and Caribbean countries included in table 4, only nine gained world market share between 1985 and 1998, while four saw no change. The largest number (12 countries) lost ground, some of them, such as Brazil and Venezuela, to a significant degree. Among the seven gainers were Mexico and six countries in the Caribbean basin. Although Argentina and Chile rank second and third, respectively, Mexico gained more than twice as much as all the other eight countries whose share increased put together.

The rise of the Central American and Caribbean countries (Costa Rica, Dominican Republic, El Salvador, Guatemala and Honduras) should not be dismissed because of their low absolute share of world trade. Rather, it should be appreciated in the light of

TABLE 4

World market share, 1985-1998

(Percentages)

\begin{tabular}{|c|c|c|c|}
\hline Country & 1985 & 1998 & Difference \\
\hline Mexico & 1.55 & 2.24 & 0.69 \\
\hline Argentina & 0.37 & 0.51 & 0.14 \\
\hline Chile & 0.23 & 0.32 & 0.09 \\
\hline Costa Rica & 0.07 & 0.10 & 0.03 \\
\hline Guatemala & 0.06 & 0.08 & 0.02 \\
\hline Honduras & 0.05 & 0.07 & 0.02 \\
\hline Dominican Republic & 0.08 & 0.10 & 0.02 \\
\hline El Salvador & 0.04 & 0.05 & 0.01 \\
\hline Colombia & 0.24 & 0.24 & 0.00 \\
\hline Paraguay & 0.03 & 0.03 & 0.00 \\
\hline Nicaragua & 0.02 & 0.02 & 0.00 \\
\hline Jamaica & 0.04 & 0.04 & 0.00 \\
\hline Uruguay & 0.07 & 0.06 & -0.01 \\
\hline Cuba & 0.03 & 0.02 & -0.01 \\
\hline Guyana & 0.02 & 0.01 & -0.01 \\
\hline Suriname & 0.02 & 0.01 & -0.01 \\
\hline Bolivia & 0.04 & 0.02 & -0.02 \\
\hline Barbados & 0.02 & 0.00 & -0.02 \\
\hline Haiti & 0.03 & 0.01 & -0.02 \\
\hline Peru & 0.17 & 0.12 & -0.05 \\
\hline Panama & 0.10 & 0.05 & -0.05 \\
\hline Ecuador & 0.17 & 0.11 & -0.06 \\
\hline Trinidad and Tobago & 0.10 & 0.04 & -0.06 \\
\hline Venezuela & 0.66 & 0.41 & -0.25 \\
\hline Brazil & 1.37 & 1.01 & -0.36 \\
\hline
\end{tabular}

Source: The authors, on the basis of the CAN 2000 software. the extremely low shares they held at the start of the period. The fact that their performance has been positive is in itself deserving of attention, given the difficult starting conditions. The advances made by Argentina and Chile have followed different patterns. While Argentina's trade has progressed essentially because of automobile and energy exports to Mercosur, Chile has developed an export trade that is quite diversified in terms of destinations, although it is largely confined to processed and unprocessed natural resources. ${ }^{5}$

If Latin America is divided into two groups, Mexico and the Caribbean Basin on the one hand and South America on the other, a very marked contrast emerges in their trade performance and international competitiveness. ${ }^{6}$ While Mexico and the Caribbean Basin increased their competitiveness sharply (from $2.1 \%$ to $2.8 \%$ between 1985 and 1998), the opposite happened in South America, whose international market share fell from $3.3 \%$ to $2.8 \%$ between those years. In terms of products, the market share of South America increased in sectors that were not very dynamic in world trade (natural resources and manufactures based on them), while the exports of Mexico and the Caribbean Basin centred on non-natural resource-based manufactures whose international trade performance was highly dynamic. The same pattern can be seen in the export structure.

The 10 main exports of South America are almost all natural resources such as crude oil, animal feed, petroleum derivatives, coffee, copper, fruit and nuts, the sole exception being the compensated trade of the Mercosur automotive industry, which largely accounts for Argentina's increased competitiveness (table 5). Mexico and the Caribbean Basin, on the other hand, specialize in non-natural resource-based manufactures such as motor vehicles, electronics and wearing apparel. Where international competitiveness is concerned, they are two different worlds.

Brazil, an economy of continental proportions, merits special consideration. The domestic market has traditionally been very important for the strategic decision-making of companies located in the country, but other factors would suggest that Brazil's lack of

\footnotetext{
${ }^{5}$ The differing importance of Mercosur in the two cases is illustrated by the fact that Argentina's share of industrialized country markets fell from $0.31 \%$ to $0.22 \%$ in $1985-1998$, while Chile's rose from $0.21 \%$ to $0.26 \%$.

${ }^{6}$ This has been described in Reinhardt and Peres (2000) as the existence of two different international trading styles "north and south of the Panama canal".
} 
South America: Competitiveness in world imports, 1985-1998

(Percentages)

\begin{tabular}{|c|c|c|c|c|c|c|}
\hline & & & 1985 & 1990 & 1995 & 1998 \\
\hline I. Market share & & & 3.34 & 2.74 & 2.73 & 2.81 \\
\hline 1. Natural resources ${ }^{\mathrm{a}}$ & & & 7.12 & 7.59 & 8.93 & 10.03 \\
\hline 2. Manufactures based on natural resources ${ }^{b}$ & & & 5.03 & 4.33 & 4.55 & 4.59 \\
\hline 3. Manufactures not based on natural resources ${ }^{c}$ & & & 1.21 & 1.13 & 1.11 & 1.17 \\
\hline - Low-technology & & & 1.93 & 1.73 & 1.66 & 1.53 \\
\hline - Medium-technology $\mathrm{y}^{\mathrm{e}}$ & & & 1.16 & 1.18 & 1.32 & 1.51 \\
\hline - High-technology ${ }^{\mathrm{f}}$ & & & 0.45 & 0.35 & 0.28 & 0.38 \\
\hline 4. Others ${ }^{g}$ & & & 2.08 & 1.14 & 1.33 & 1.42 \\
\hline II. Export structure & & & 100.0 & 100.0 & 100.0 & 100.0 \\
\hline 1. Natural resources ${ }^{\mathrm{a}}$ & & & 49.2 & 44.3 & 43.6 & 44.0 \\
\hline 2. Manufactures based on natural resources ${ }^{b}$ & & & 29.2 & 28.3 & 27.6 & 25.7 \\
\hline 3. Manufactures not based on natural resources ${ }^{\mathrm{c}}$ & & & 19.7 & 26.0 & 27.1 & 28.5 \\
\hline - Low-technology & & & 8.2 & 10.6 & 10.1 & 9.0 \\
\hline - Medium-technology $\mathrm{y}^{\mathrm{e}}$ & & & 9.9 & 13.5 & 15.1 & 16.7 \\
\hline - High-technology $\mathrm{y}^{\mathrm{f}}$ & & & 1.6 & 1.9 & 2.0 & 2.8 \\
\hline 4. Others ${ }^{g}$ & & & 1.9 & 1.4 & 1.7 & 1.8 \\
\hline III. Ten leading exports by contribution ${ }^{h}$ & $\mathbf{A}$ & B & 52.3 & 44.6 & 40.8 & 41.1 \\
\hline 333 Petroleum oils, crude & & + & 12.3 & 10.0 & 11.2 & 11.1 \\
\hline 081 Feeding stuff for animals (not including unmilled cereals) & & + & 4.4 & 4.4 & 4.7 & 4.3 \\
\hline 334 Products derived from petroleum, refined & & - & 10.7 & 7.2 & 4.4 & 4.3 \\
\hline 071 Coffee and coffee substitutes & & - & 9.9 & 4.6 & 4.1 & 4.1 \\
\hline 682 Copper & & - & 3.2 & 4.5 & 3.7 & 3.6 \\
\hline 057 Fruit and nuts (not including oil nuts), fresh or dried & & + & 2.9 & 3.9 & 3.6 & 3.6 \\
\hline 281 Iron ore and concentrates & & + & 4.1 & 4.4 & 3.3 & 3.1 \\
\hline 222 Oil seeds and oleaginous fruits & & + & 2.2 & 2.4 & 2.1 & 2.5 \\
\hline 781 Passenger motor vehicles & & + & 0.6 & 0.7 & 1.2 & 2.3 \\
\hline 287 Ores and concentrates of base metals & & + & 2.1 & 2.4 & 2.4 & 2.3 \\
\hline
\end{tabular}

Source: The authors, on the basis of the CAN 2000 software. The product groups are based on the Standard International Trade Classification (SITC, revision 2).

a Contains 45 basic products that are simple to process, includes concentrates.

b Contains 65 items: 35 agricultural/forestry groups and 30 others (mainly metals, excluding steel, plus petroleum products, cement, glass, etc.).

${ }^{\mathrm{c}}$ Contains 120 groups representing the sum of ${ }^{\mathrm{d}}+{ }^{\mathrm{e}}+{ }^{\mathrm{f}}$.

d Contains 44 items: 20 groups from the textile and garment category, plus 24 others (paper products, glass and steel, jewellery).

e Contains 58 items: five groups from the automotive industry, 22 from the processing industry and 31 from the engineering industry.

f Contains 18 items: 11 groups from the electronics category, plus another seven (pharmaceutical products, turbines, aircraft, instruments).

g Contains nine unclassified groups (mainly from section 9).

${ }^{\mathrm{h}}$ In column A: groups belonging (*) to the 50 most dynamic in world imports, 1985-1998. In column B: groups where South America gained (+) or lost (-) world import market share, 1985-1998.

international competitiveness is worrying even from that point of view. For more than a decade, the country's overriding policy objective has been to increase its penetration of the world market. The results are not encouraging. Although some activities with a high technological content have been added to the country's exports (aircraft, cellular telephones, computers), their proportion of total exports is still small, and there is no sign of it being able to rise significantly in the short term (Miranda, 2000). Again, Brazil's long-term competitiveness indicators have declined, indicating a weakening in its international position that cannot be attributed to the size of its economy.

The countries of South America have failed to enhance their international competitiveness because they have only a small presence in dynamic manufactures, whether produced by local companies (as occurred in Japan, the Republic of Korea and Taiwan) or by transnational enterprises' IIPS. They have been unable to attract this kind of FDI, and are thus at a 
TABLE 6

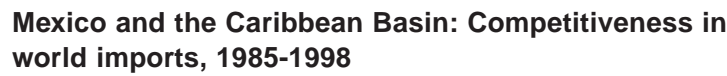

\begin{tabular}{|c|c|c|c|c|c|c|}
\hline & & & 1985 & 1990 & 1995 & 1998 \\
\hline I. Market share & & & 2.13 & 1.73 & 2.21 & 2.80 \\
\hline 1. Natural resources ${ }^{\mathrm{a}}$ & & & 5.01 & 3.61 & 3.31 & 3.69 \\
\hline 2. Manufactures based on natural resources ${ }^{b}$ & & & 1.43 & 1.15 & 1.30 & 1.53 \\
\hline 3. Manufactures not based on natural resources ${ }^{\mathrm{c}}$ & & & 1.17 & 1.41 & 2.22 & 2.95 \\
\hline - Low-technology ${ }^{\mathrm{d}}$ & & & 1.06 & 1.44 & 2.40 & 3.40 \\
\hline - Medium-technology & & & 1.09 & 1.43 & 2.35 & 2.97 \\
\hline - High-technology $\mathrm{y}^{\mathrm{oj}}$ & & & 1.50 & 1.34 & 1.84 & 2.55 \\
\hline 4. Others ${ }^{g}$ & & & 1.83 & 1.84 & 2.18 & 2.60 \\
\hline II. Export structure & & & 100.0 & 100.0 & 100.0 & 100.0 \\
\hline 1. Natural resources ${ }^{\mathrm{a}}$ & & & 54.4 & 33.3 & 20.0 & 16.2 \\
\hline 2. Manufactures based on natural resources ${ }^{b}$ & & & 13.1 & 11.9 & 9.7 & 8.6 \\
\hline 3. Manufactures not based on natural resources ${ }^{c}$ & & & 29.9 & 51.3 & 66.9 & 71.9 \\
\hline - Low-technology ${ }^{\mathrm{d}}$ & & & 7.1 & 13.8 & 18.0 & 20.1 \\
\hline - Medium-technology & & & 14.6 & 25.7 & 33.1 & 32.8 \\
\hline - High-technology $\mathrm{y}^{\mathrm{f}}$ & & & 8.2 & 8.0 & 15.8 & 19.0 \\
\hline 4. Others ${ }^{g}$ & & & 2.7 & 3.6 & 3.4 & 3.3 \\
\hline III. Ten leading exports by contribution ${ }^{h}$ & $\mathbf{A}$ & B & 43.3 & 36.2 & 37.0 & 38.9 \\
\hline 781 Passenger motor vehicles & & + & 0.6 & 4.4 & 7.6 & 7.5 \\
\hline 333 Petroleum oils, crude & & - & 33.2 & 15.6 & 7.6 & 6.2 \\
\hline 773 Equipment for distributing electricity & $*$ & + & 1.8 & 3.3 & 3.8 & 3.9 \\
\hline 846 Clothing accessories, knitted or crocheted & $*$ & + & 0.6 & 1.2 & 2.4 & 3.2 \\
\hline 761 Television receivers & $*$ & + & 0.4 & 1.8 & 2.7 & 3.2 \\
\hline 764 Telecommunications equipment and parts and accessories & $*$ & - & 2.4 & 2.2 & 2.9 & 3.2 \\
\hline 752 Automatic data processing machines & $*$ & + & 0.1 & 1.3 & 1.9 & 3.1 \\
\hline 782 Motor vehicles for the transport of goods & & + & 0.4 & 0.4 & 2.2 & 2.9 \\
\hline $\begin{array}{l}931 \text { Special transactions and commodities not classified } \\
\text { according to kind }\end{array}$ & $*$ & + & 1.9 & 2.9 & 2.8 & 2.8 \\
\hline 784 Parts and accessories for motor vehicles & & + & 1.9 & 3.1 & 3.0 & 2.8 \\
\hline
\end{tabular}

Source: The authors, on the basis of the CAN 2000 software. The product groups are based on the Standard International Trade Classification (SITC, revision 2).

${ }^{a}$ Contains 45 basic products that are simple to process, includes concentrates.

b Contains 65 items: 35 agricultural/forestry groups and 30 others (mainly metals, excluding steel, plus petroleum products, cement, glass, etc.).

${ }^{\mathrm{c}}$ Contains 120 groups representing the sum of ${ }^{\mathrm{d}}+{ }^{\mathrm{e}}+{ }^{\mathrm{f}}$.

${ }^{\mathrm{d}}$ Contains 44 items: 20 groups from the textile and garment category, plus 24 others (paper products, glass and steel, jewellery).

e Contains 58 items: five groups from the automotive industry, 22 from the processing industry and 31 from the engineering industry.

${ }^{\mathrm{f}}$ Contains 18 items: 11 groups from the electronics category, plus another seven (pharmaceutical products, turbines, aircraft, instruments).

g Contains nine unclassified groups (mainly from section 9 ).

${ }^{\mathrm{h}}$ In column A: groups belonging (*) to the 50 most dynamic in world imports, 1985-1998. In column B: groups where Mexico and the Caribbean Basin gained (+) or lost (-) world import market share, 1985-1998.

disadvantage to countries that have done so, such as China, Malaysia, Singapore and Thailand in Asia, Ireland and Spain in Europe, and even Mexico. In other words, South America has not been a magnet for FDI by the transnational companies that are developing IIPS to increase the efficiency of their operations. They have been able to attract FDI from transnational companies seeking to enter national markets for services (telecommunications, ${ }^{7}$ electricity distribution, financial services), but these activities, while they may have a positive effect on the systemic competitiveness of the beneficiary countries, do not have a direct impact on their international market share.

\footnotetext{
${ }^{7}$ See ECLAC (forthcoming), chapter IV.
} 
The case of Mexico and the Caribbean Basin is completely different (table 6). These countries have made great progress with their international competitiveness; this success, however, has not acted as an engine for growth in their economies, as has been the case in a number of Asian countries.

The ability of the Caribbean Basin to compete rests essentially on a single industry, wearing apparel or garments, and on a single market, the United States. During the period 1980-2000, many Caribbean countries took advantage of the new opportunities for exporting garments to the United States market that arose because of a production sharing mechanism ${ }^{8}$ allowing greater access to that market with low tariffs and higher quotas for countries that assembled garments using United States inputs. Production sharing brought few benefits to the assembling countries since not only did this mechanism penalize the inclusion of local inputs, but the countries involved had little say in how the mechanism was used and tended to become embroiled in incentive wars to attract FDI from transnational enterprises (Mortimore and Peres, 1998). Ultimately, the system hindered efforts to create a local industry based on domestic inputs (Mortimore, 1999).

The experience of Mexico was similar to that of the Caribbean Basin, as production sharing was the key to the improvement in the country's international competitiveness. In this case, however, the product range extended beyond garments to include the electronics and automotive industries, with some of the world's largest transnational companies in these industries carrying out their international operations in Mexico (Dussel, 1999 and 2000). The initiative that set the Mexican experience apart from the Caribbean one was the North American Free Trade Agreement (NAFTA) (Mortimore, Buitelaar and Bonifaz, 2000), as a result of which Mexico not only obtained more favourable access to the North American market, but benefited from the application of the rules of origin which operate within that integration system. Investing companies have to comply with those rules for their output to be regarded as being of North American origin (Mortimore, 1998d and Calderón, Mortimore and Peres, 1996). ${ }^{9}$

Mexico has been one of the great gainers in terms of international competitiveness, something that has translated into the establishment of modern plants and a boost to the Mexican economy in certain internationalizing industries, such as the automotive, electronics and wearing apparel industries. Mexican export success has not resulted in balanced development and sustained economic growth. Two parallel economies exist side by side in the country: a modern one, whose growth is based on exports to the North American market, and a traditional one, based on agriculture and other undynamic activities. The linkages between the two economies are unsatisfactory and there is little integration between the modern economy and the rest of the national economy, which imports many of its inputs and draws its dynamism from abroad.

\section{III}

\section{The structure and behaviour of economic agents}

\section{The transnationalization of the Latin American economies}

The globalization process is clearly revealed by the preponderance of transnational companies. It is calculated that these companies account for three quarters of all FDI movements and two thirds of

${ }^{8}$ The nature and effects of the production sharing mechanism are explained in greater detail in ECLAC (2000), chapter IV. international trade (one third in the form of intracompany operations and one third in the form of trade with unrelated companies). Flows of FDI increased enormously in the 1990s to exceed US $\$ 850$ billion in 1999 , more than double the average for the period 19901996. The FDI going to developing countries thus grew

\footnotetext{
${ }^{9}$ A detailed analysis of the Mexican case can be found in ECLAC (2000), chapter II.
} 
more strongly, becoming the main source of long-term financing (World Bank, 1999). ${ }^{10}$

These large FDI flows are due to the international expansion of transnational companies, and reveal the growing presence and importance of these companies in the emerging single market. Investment of this type has two main uses: the purchase of existing assets in the form of mergers and acquisitions,,${ }^{11}$ and the creation of new assets in the form of IIPS. It is estimated that half of all the investment that arrived in Latin America in the 1990s went on purchasing existing assets. The result of the whole process has been to strengthen the strategic importance of transnational companies in the region's countries (ECLAC, 1998 and 2000 and Stumpo, 1998).

Mergers and acquisitions were of particular importance in the FDI going to Latin America in the 1990s, when the region increased its share in the world total of operations of this kind so that in 1999 it accounted for $13.5 \%$ by value. Estimates by Mendes de Paula, Pereira Silva and Couto da Silva (2000), based on 1,685 transactions for which Thomson Financial Securities Data gives values (out of a total of 3,291), show that foreign companies accounted for $53.6 \%$ of all mergers and acquisitions in Argentina, Brazil, Chile and Mexico in 1990-1999. ${ }^{12}$ This share was particularly high in Argentina and Chile, where it exceeded 60\%. The exception was Mexico, where domestic firms played a very active role in privatizations of publicsector enterprises, and took and retained control of the largest privatized firm (Teléfonos de México, or Telmex, acquired by Carso Group).

Domestic companies also participated in the mergers and acquisitions process, carrying out operations to the value of US\$ 135.3 billion. The information available shows, however, particularly in the cases of Argentina and Mexico, that after an initial stage in the early 1990s when the main buyers of privatized enterprises were local companies or investors, ownership was restructured in such a way that foreign companies or investors took control of the formerly State-owned enterprises. Two cases whose scale makes

\footnotetext{
10 To the extent of $56.4 \%$ in 1998 , as compared with $24.3 \%$ in 1990 (World Bank, 1999).

${ }^{11}$ In the industrial countries there are many merger operations whereby two firms are fused into one, as well as acquisitions of one firm by another. In the rest of the world, mergers are scarce, and acquisitions are the most common type of operation.

${ }^{12}$ These four countries received $75 \%$ of all FDI of this type arriving in the region.
}

them particularly important are those of commercial banking in Mexico and public services, including telephony, in Argentina (Garrido, 2000 and Kulfas, 2000). In both cases, privatized companies acquired by local investors in the first half of the 1990s were sold on to foreign partners or investors in the second half of the decade.

In sectoral terms, the situation in the four countries referred to varied greatly depending on the macroeconomic circumstances, the time of privatization and the economic structure of each country. For the four countries taken together, $35 \%$ by value of all operations took place in the infrastructure sectors (including telecommunications and electrical energy), $19 \%$ in the financial sector and $17 \%$ in manufacturing industry. Operations in the infrastructure and financial sectors exceeded those in industry in all the countries except Brazil, where industry accounted for $22 \%$ of the total value of operations, this being the result of privatizations in the iron and steel and petrochemical industries in the early 1990s (Mendes de Paula, Pereira Silva and Couto da Silva, 2000). In Argentina, on the other hand, acquisitions in the oil sector predominated, exceeding by a wide margin those carried out in communications, banking and food and drink (Kulfas, 2000).

The large net inflows of FDI into Latin America -unthinkable just a few years previously- had major effects on the economic structure of the region, with the main economic agents becoming transnationalized. One consequence of the globalization process and economic reforms in Latin America was the strengthening of foreign companies and the weakening of State ones, especially in the latter years. During the 1990s, transnational enterprises increased their activity in Latin America, consolidating their penetration of the manufacturing sector -particularly in the automotive industry (Mortimore, 1998a and 1998b)- and increasing their share of regional exports. In the service sector, they took advantage of liberalization, deregulation and privatization to enter areas where FDI had previously had only limited access. In the ranks of the region's largest firms, the rise in the number of transnationals coincided with the near disappearance of State-owned enterprises, while the number of locally owned private-sector companies remained virtually unchanged (ECLAC, 2000).

Further evidence of the transnationalization process in Latin America is provided by the constant rise of FDI-related indicators. Net inflows increased twelvefold between 1980 and 1998. Compared with gross fixed 
TABLE 7

Latin America: Results of the leading companies in the 1990s

(Percentages)

\begin{tabular}{|c|c|c|c|}
\hline Share in & 1990-1992 & $1994-1996^{a}$ & 1998-1999 \\
\hline \multicolumn{4}{|c|}{ Sales of the 500 largest companies } \\
\hline Foreign & 27.4 & 32.1 & 43.7 \\
\hline Local private-sector & 39.4 & 41.0 & 37.2 \\
\hline State-owned & 33.2 & 26.9 & 19.1 \\
\hline Total & 100.0 & 100.0 & 100.0 \\
\hline \multicolumn{4}{|c|}{ Sales of the 100 largest manufacturing companies } \\
\hline Foreign & 53.2 & 59.3 & 61.7 \\
\hline Local private-sector & 42.6 & 38.6 & 37.3 \\
\hline State-owned & 4.2 & 2.1 & 1.2 \\
\hline Total & 100.0 & 100.0 & 100.0 \\
\hline \multicolumn{4}{|c|}{ Exports of the 200 largest exporters } \\
\hline Foreign & $\ldots$ & 29.2 & 43.2 \\
\hline Local private-sector & $\ldots$ & 35.9 & 32.7 \\
\hline State-owned & $\ldots$ & 34.9 & 24.1 \\
\hline Total & $\ldots$ & 100.0 & 100.0 \\
\hline
\end{tabular}

Source: Information Centre of the Unit on Investment and Corporate Strategies, ECLAC.

a The export data are averages for 1995-1996.

capital formation and GDP, these inflows grew more than fourfold. Again, more than half of the total stock of FDI in Latin America as of 1998 had arrived in the region during that same decade. In short, a major process of transnationalization took place in the region, and transnational companies became the dominant economic agents of the 1990s.

\section{Changes in corporate structure and strategy}

a) The advance of transnationals

Between 1990-1992 and 1998-1999, the best performance among the 500 largest companies in Latin America, measured by consolidated sales, was that achieved by the subsidiaries of transnational enterprises. The number of foreign firms in the list increased from 149 to 230 and their share of total sales rose from $27.4 \%$ to $43 \%$. By contrast, the number of State-owned enterprises fell from 87 to 64 and their share of sales fell from $33.2 \%$ to $18.8 \%$ (table 7 ).

As regards the activities of these 500 companies, the most important changes took place in extractive and service businesses. The sales share of the primary sector fell from $27.7 \%$ to $19.3 \%$, while that of the service sector rose from $29.9 \%$ to $38 \%$. Manufacturing companies retained their dominant share of some $42 \%$ of total sales. The strong and steady growth of services is largely due to the liberalization of telecommunications and electricity and the privatization of the public-sector companies that supplied these services.

Changes among the 100 largest manufacturing companies were also considerable. Between 1990-1992 and 1998-1999, the share of sales accounted for by subsidiaries of transnational enterprises rose from $53.2 \%$ to $62.7 \%$, while that of domestic private-sector companies fell from $42.6 \%$ to $37.3 \%$. State-owned enterprises virtually disappeared from the equation. About half of all sales by foreign companies were in the motor vehicles and parts subsector, which indicates that the impact of transnational companies in the Latin American industrialization process has been concentrated in this area, primarily in Argentina, Brazil and Mexico.

In exports, the area where international competitiveness is most clearly reflected, transnational companies increased their share in the total exports of the region's 200 largest exporters from $29.2 \%$ in 1990 1992 to $43.2 \%$ in 1998-1999; at the same time, the share of domestic private-sector and State-owned companies declined. These 200 large companies had annual exports of US\$ 134.9 billion in 1997-1999, or 47\% of the region's total exports by value. 
TABLE 8

Latin America: Twenty largest exporters, 1999

(Millions of dollars)

\begin{tabular}{|c|c|c|c|}
\hline Company & Ownership & Activity & Exports \\
\hline 1. Petróleos de Venezuela (PDVSA) & State & $\begin{array}{l}\text { Extraction of crude oil and natural gas. Refining } \\
\text { and petrochemicals. }\end{array}$ & 16299 \\
\hline 2. Petróleos Mexicanos (PEMEX) & State & $\begin{array}{l}\text { Extraction of crude oil and natural gas. Refining } \\
\text { and petrochemicals. }\end{array}$ & 9914 \\
\hline 3. General Motors Mexico & Foreign & Production of motor vehicles. & 5050 \\
\hline 4. Volkswagen Mexico & Foreign & Production of motor vehicles. & 5040 \\
\hline 5. Chrysler Mexico & Foreign & Production of motor vehicles. & 3792 \\
\hline 6. IBM Mexico & Foreign & $\begin{array}{l}\text { Production of information technology, office } \\
\text { and accounting machinery. }\end{array}$ & 3000 \\
\hline 7. Cementos Mexicanos (CEMEX) & Local private-sector & Cement production. & 2665 \\
\hline 8. Corporación Nacional del Cobre Chile (CODELCO) & State & Extraction of metal ores (copper). & 2501 \\
\hline 9. Ford Mexico & Foreign & Production of motor vehicles. & 2330 \\
\hline 10. Empresa Colombiana de Petróleos (ECOPETROL) & State & $\begin{array}{l}\text { Extraction of crude oil and natural gas. } \\
\text { Refining and petrochemicals. }\end{array}$ & 2170 \\
\hline 11. Empresa Brasileira de Aeronáutica (EMBRAER) & Local private-sector & Aircraft production. & 1692 \\
\hline 12. Nissan Mexico & Foreign & Production of motor vehicles. & 1586 \\
\hline 13. Companhia Vale do Rio Doce (CVRD) (Brazil) & Local private-sector & Mining, cellulose, aluminium, transport. & 1542 \\
\hline 14. Yacimientos Petrolíferos Fiscales (YPF) (Argentina) & Foreign & Extraction of crude oil and natural gas. Refining. & 1436 \\
\hline 15. Fed. Nac. de Cafeteros (FEDECAFE) (Colombia) & Local private-sector & Coffee marketing. & 1418 \\
\hline 16. Odebrecht (Brazil) & Local private-sector & $\begin{array}{l}\text { Construction and engineering. Chemicals and } \\
\text { petrochemicals. Cellulose. }\end{array}$ & 1317 \\
\hline 17. CINTRA (Aeroméxico and Mexicana de Aviación) & Local private-sector & $\begin{array}{l}\text { Air transportation of passengers and goods and } \\
\text { allied services. }\end{array}$ & 1185 \\
\hline 18. Philips (Mexico) & Foreign & $\begin{array}{l}\text { Production of radio, television and communications } \\
\text { equipment and apparatus. }\end{array}$ & 1095 \\
\hline 19. Cargill Argentina & Foreign & $\begin{array}{l}\text { Inputs for the agricultural sector. Ingredients for the food } \\
\text { industry. }\end{array}$ & 1084 \\
\hline 20. GRUMA-Grupo Maseca (Mexico) & Local private-sector & $\begin{array}{l}\text { Manufacture of food products } \\
\text { (maize flour and tortillas). }\end{array}$ & 1047 \\
\hline
\end{tabular}

Source: Information Centre of the Unit on Investment and Corporate Strategies, ECLAC.

Table 8 lists the exporting companies in the region that had more than US\$ 1 billion in foreign sales in 1999. Of the 20 companies in the list, which had US\$ 66.2 billion in exports between them, ${ }^{13}$ nine were local private-sector firms, seven were foreign and four were State-owned; foreign companies held five of the top 10 places, along with four State-owned companies and just one local private-sector one (Cemex). Only one local private-sector company is active in an area that is not directly linked with the extraction or processing of natural resources: Empresa Brasileira de Aeronáutica (Embraer), an aircraft manufacturer, which ranks eleventh in the list.

The fact that State enterprises still account for a quarter of all exports by the 200 largest exporters (table 7) shows that privatization has come up against

13 This figure represents approximately half of all exports by the 200 largest exporters and a quarter of the region's total exports. limits in the region, something that is often forgotten. In particular, the region's two largest exporters are Petróleos de Venezuela (PDVsa) and Petróleos Mexicanos (Pemex), while the 10 largest also include the Corporación Nacional del Cobre (Codelco) of Chile and the Empresa Colombiana de Petróleos (Ecopetrol).

Combining the information from tables 7 and 8 makes it possible to study the strategies and performance of large companies, particularly transnational and local private-sector ones. Analysis of the impact of State enterprises is beyond the scope of this work, but could appropriately be carried out in studies on the oil sector and, to a lesser extent, copper mining. ${ }^{14}$

\footnotetext{
${ }^{14}$ Small and medium-sized enterprises, although they have made progress with exporting, still account for only a very small percentage, as almost all their output goes to domestic markets (Peres and Stumpo, 2000).
} 
TABLE 9

Latin America: The strategies of transnational companies

in the region in the 1990s

\begin{tabular}{|c|c|c|c|}
\hline Sector Strategy & $\begin{array}{l}\text { Efficiency- } \\
\text { seeking }\end{array}$ & $\begin{array}{l}\text { Raw materials- } \\
\text { seeking }\end{array}$ & $\begin{array}{l}\text { Market access-seeking } \\
\text { (national or regional) }\end{array}$ \\
\hline Primary & & $\begin{array}{l}\text { Oil/gas: Argentina, } \\
\text { Bolivia, Brazil, } \\
\text { Colombia and Venezuela } \\
\text { Minerals: Argentina, } \\
\text { Chile and Peru }\end{array}$ & \\
\hline
\end{tabular}

Vehicles: Mexico

Electronics: Mexico and

Manufactures

Vehicles: Mercosur

Agroindustry: Argentina, Brazil and Mexico

Chemicals: Brazil

Garments: Mexico and

Caribbean Basin

Cement: Colombia, Dominican Rep.

and Venezuela

\begin{tabular}{ll}
\hline & Finance: Argentina, Brazil, Chile, Colombia, \\
& Mexico, Peru and Venezuela \\
& Telecommunications: Argentina, Brazil, Chile and \\
Pervices & Peru \\
& Retail: Argentina, Brazil, Chile and Mexico \\
& Electricity: Argentina, Brazil, Chile, Colombia \\
and Central America & Gas distribution: Argentina, Brazil, Chile and \\
& Colombia \\
& Tourism: Mexico and Caribbean Basin
\end{tabular}

Source: ECLAC, Division of Production, Productivity and Management, Unit on Investment and Corporate Strategies.

In manufacturing, the direction of international markets and the renewed patterns of competition resulting from trade and financial liberalization aroused the interest of new entrants and forced transnational companies already operating in the region to reconsider their strategies. Macroeconomic stabilization and structural reform programmes meant a radical shift in the macroeconomic variables of the region's economies (exchange rates, interest rates) and in the institutions and regulatory frameworks applying to economic agents (Katz, 2000 and Stallings and Peres, 2000).

Some transnational companies withdrew (opting in some cases to supply local markets through exports), or rationalized their operations to defend or increase their market share (generally by means of defensive strategies designed to cope with competition from exports), or restructured their activities, which involved making new investments that took particular account of changes in the national, subregional (NAFTA and Mercosur) and international environments (Mortimore, 2000). In manufacturing industry it is possible to identify two sets of basic strategies, the objectives of which, respectively, are to increase the efficiency of the IIPS created by transnational companies and to obtain access to national and subregional markets for manufactured goods (table 9).

The first strategy has mainly involved investing in the motor vehicle and vehicle parts, information technology, electronics and wearing apparel industries in Mexico and the Caribbean. ${ }^{15}$ The second has involved large investments in the automotive and food subsectors and in the chemical and machinery industries to supply local markets. In Mercosur, particularly, investments have been made by companies with a large presence to defend their market share, particularly for compact cars. ${ }^{16}$ New entrants have also arrived in search of market niches. ${ }^{17}$

\footnotetext{
15 The most representative examples in the automotive industry are the operations of General Motors, Ford, Daimler-Chrysler, Volkswagen, Nissan and Lear Corp., in Mexico. In the area of information technology, the largest investments are those of IBM and Hewlett Packard in Mexico and Intel in Costa Rica. The operations of Sony, Philips, Samsung, Matsushita and General Electric in Mexico illustrate what is happening in the electronics industry. As regards wearing apparel, the best examples are provided by Sara Lee and Fruit of the Loom in Mexico and the Caribbean Basin.

${ }^{16}$ For example, Ford, General Motors, Volkswagen and Fiat.

${ }^{17}$ This is the case with Chrysler, Renault, BMw, Toyota and Honda.
} 
Meanwhile, deregulation and privatization in the Latin American economies have opened up new investment opportunities in sectors to which access was previously restricted for the private sector in general, and foreign companies in particular. This has led to a massive influx of companies that did not previously have a large presence in Latin America, especially in the areas of services, infrastructure and extraction. Two further strategies can thus be identified: foreign investors in the region are seeking access to national markets in service and infrastructure sectors, and access to sources of raw materials.

In service businesses, the size of the local market, regulatory systems and technological change have been determining factors in the decisions made by foreign investors. Their impact is measured by their contribution to the systemic competitiveness of the economy, the access to new products and services they give the population, and the spread of international best practice. This is of the greatest importance to Latin America and the Caribbean, as in recent years investment in the service sector has grown considerably, the prime examples being telecommunications, financial services and electricity, particularly in Mercosur and Chile. ${ }^{18}$

The entry of transnational companies into extractive activities has been characterized by renewal of the production organization model, the application of new technologies and the reform of regulatory systems in countries that have abundant natural resources. ${ }^{19}$ In general, the impact of these investments, which tend to benefit from very favourable tax waivers, has been measured by the extent to which exports of natural resources have increased and to which the necessary infrastructure has been constructed. ${ }^{20}$

Of the strategies adopted by transnational enterprises, two have a direct influence on a country's trade performance: the search for raw materials, and efficiency-seeking. The search for raw materials has been a very important strategy, and still is for the countries that are invested in, even though primary

\footnotetext{
${ }^{18}$ In telecommunications, the investments of Telefónica of Spain, Italia Telecom and BellSouth. In financial services, Banco Santander Central Hispano (вSCH), Banco Bilbao Vizcaya Argentaria (BBVA) and Citibank. In commerce, Carrefour, Wal-Mart, Royal Ahold and Groupe Casino Guichard. In electrical power, the leading operations are those of Endesa España, AES Corporation and Duke Energy.

${ }^{19}$ See ECLAC (forthcoming), chapter II.

${ }^{20}$ The leading companies involved include Repsol, Royal Dutch Shell, Exxon and Broken Hill Proprietary.
}

products are not a very dynamic component of international trade. Foreign direct investment plays an important role in decisions on major projects relating to natural resources for export; but these projects come up against natural constraints, and their impact on the economic growth of a developing country has clear limitations. The development theory that deals with these issues states that, ultimately, the production of raw materials yields decreasing returns and displays low income elasticity in international trade. ${ }^{21}$

Efficiency-seeking is a strategy of growing importance to developing countries. In pursuit of efficiency, some industries have been relocated on a large scale, examples being the wearing apparel, automotive and electronics industries, with a view to taking advantage of lower assembly or production costs in particular places (UNCTAD, 2000). Manufacturing companies are investing outside their countries of origin to build IIPS and thereby adapt to the globalization process. Consequently, large transnational companies are setting up specialized modern plants in certain countries where they can produce more cheaply without losing access to their main markets. It is here that domestic policies in developing countries can have an effect by influencing the siting of FDI and thus the generation of the technology flows that come with such investment.

\section{b) Specialization by locally owned groups}

Large locally owned private-sector groups and companies ${ }^{22}$ have a strong position in Latin American markets, owing to processes that have occurred as part of the structural changes seen since the early 1980s in national economies and internationally. These large local groups and companies, along with the subsidiaries of transnational enterprises, are the largest and most dynamic business units operating in the region's

\footnotetext{
${ }^{21}$ Economic expansion derives from two sources: the increase in factors of production and the increase in production per factor unit. Where returns are decreasing, there is a limit to what growth can be achieved through greater utilization of factors of production, which means that efficiency needs to be improved if sustainable per capita income growth is to be generated (Krugman, 1994).

${ }^{22}$ Although the distinction should be drawn whenever reference is made to large companies and the businesses concerned are actually groups or conglomerates, the total number of large, independent locally owned companies in the region is very small. Most large companies form part of formal or informal groups, as different laws or investor practices dictate. This section has been based largely on Garrido and Peres (1998), and on the analyses of national cases included in Peres (coord., 1998).
} 
industry. This shared dominance has tended to consolidate since most State companies were privatized.

The competitive position of these firms is jeopardized by their own structural characteristics, in particular their small size as compared with their international competitors and their position in technologically mature sectors that are growing relatively slowly in the world market. ${ }^{23}$ They have not grown strongly enough to draw the rest of their national economies along with them, which means it is difficult to regard their position in the competition as one of real leadership.

The great majority of the large locally owned private-sector groups and companies that now hold a prominent place in Latin American business were created during the import substitution industrialization process ${ }^{24}$ although some companies date back to the early twentieth century, when industrialization began in the region's more advanced countries. ${ }^{25}$ Alongside those companies founded before and during the import substitution process are some new ones, a number of them very powerful, which were founded or developed during the structural reforms carried out from the 1980s onward. These new organizations have emerged both from the privatization of traditional businesses (Enersis in Chile, subsequently sold to Endesa España) and from dynamic conglomeration processes based on a portfolio logic (the Carso group in Mexico).

One characteristic of these companies that is essential to any evaluation of their impact on the competitiveness of the region's countries is the sector of activity they operate in, and the influence they exert there. Garrido and Peres (1998), who studied the five largest companies in 19 industrial sectors in 1996, highlight the concentration of Latin American industry.

\footnotetext{
${ }^{23}$ Among the 100 largest industrial enterprises, Garrido and Peres (1998) show that, while large local companies increased their sales from an average of US\$ 827 million apiece in 1990 to US\$ 1.345 billion in 1996, they are still smaller than the subsidiaries of foreign firms (US\$ 1.879 billion). Furthermore, the sales of these large local companies often do not amount to so much as $10 \%$ of those of the international enterprises they compete with.

${ }^{24}$ The proportion of the largest companies of today that were created or saw their peak development during the import substitution phase is strikingly large. By the end of the 1970s they already held a position as important as they do today, examples being Votorantim in Brazil, Acindar in Argentina and the Compañía de Acero del Pacífico in Chile, although they have all had to carry out profound restructuring to maintain their position.

${ }^{25}$ Bunge y Born in Argentina, Alpargatas in Argentina and Brazil, the core of Grupo Monterrey in Mexico, Bavaria in Colombia and the Compañía de Cervecerías Unidas in Chile, among others.
}

The 83 companies (local and foreign) that featured among the five largest in each sector had sales of US\$ 122 billion and accounted for almost 780,000 jobs in 1996, a year in which the gross industrial output of the region was some US\$750 billion, with industrial employment standing at about 8.5 million people..$^{26}$ Local companies had a share of $39.8 \%$ in the total sales of this group.

The sectors in which the sales of the five largest local firms predominated (over $66 \%$ of the total) were traditional activities involving the production of mass consumption goods or basic inputs (non-alcoholic drinks and beer, glass, petrochemicals, steel, textiles, agro-industrial products, cement, and cellulose and paper), and one metallurgical industry, the production of car parts. While domestic companies had an intermediate share (between $30 \%$ and $66 \%$ of the total) in foods, machinery and equipment ${ }^{27}$ and white goods and electronics, this share was very low or nil in certain highly technology- and marketing-intensive sectors, such as motor vehicles, computer and telephony equipment, tyres, chemicals, hygiene and cleaning items and tobacco products.

Although privatization has enabled locally owned private-sector companies to enter modern areas outside the industrial sector (one example being telecommunications, where they have had to go into partnership with large transnational firms to cope with the intense competition that exists), ${ }^{28}$ they have not secured a major share in technologically advanced manufacturing activities at the international level. ${ }^{29}$ This appreciation is confirmed by information on the 20 largest locally owned private-sector companies (industrial and non-industrial) in 1999 (table 10).

\footnotetext{
${ }^{26}$ This employment figure does not include microenterprises.

${ }^{27}$ Essentially because of the output of Condumex, a Mexican firm producing electrical conductors.

${ }^{28}$ In some cases, these groups have since sold on the privatized firms to foreign partners or investors.

${ }^{29}$ The cases where groups have entered advanced-technology industries have been very few, the most noteworthy being the investments made by Grupo Pulsar (Mexico) in biotechnology and some stakes, often short-lived, held by Brazilian groups in joint ventures for the development of software, computer equipment or consumer electronics, mainly while the reserved market policy was in force (Itautec Philco, Semp Toshiba, Sharp, NEC, CCE da Amazónia, for example). Of the 46 large companies studied in detail in Garrido and Peres (1998), just one (Sonda, Chile) could be regarded as specializing in one of the technologies characteristic of the current technological revolution (software production).
} 
TABLE 10

Latin America: Twenty largest local private-sector companies, by 1999 sales

(Millions of dollars and number of employees)

\begin{tabular}{|c|c|c|c|c|c|}
\hline Company & Country & Activity & Sales & Employees & Exports \\
\hline 1. Carso Global Telecom (TELMEX) ${ }^{\mathrm{a}}$ & Mexico & Telecommunications & 10242 & 73321 & 930 \\
\hline 2. Cementos Mexicanos (CEMEX) & Mexico & Cement & 4826 & 20902 & 2665 \\
\hline 3. Grupo Carso & Mexico & Diversified (electrical components, services) & 4272 & 42810 & 600 \\
\hline 4. Grupo Alfa & Mexico & Diversified (petrochemicals, steel) & 4240 & 35615 & 957 \\
\hline 5. Fomento Económico Mexicano (FEMSA) & Mexico & Beer and non-alcoholic drinks & 4060 & 41367 & 554 \\
\hline 6. Companhia Vale do Rio Doce (CVRD) & Brazil & Extraction of metal ores & 3901 & 10740 & 1542 \\
\hline 7. Tele Norte-Leste Participações (TELEMAR) & Brazil & Telecommunications & 3478 & $\ldots$ & $\ldots$ \\
\hline 8. Techint organization & Argentina & Iron and steel, construction & 3407 & 28461 & 647 \\
\hline 9. Compañía de Petróleos de Chile (COPEC) & Chile & $\begin{array}{l}\text { Extraction of crude oil and natural gas } \\
\text { and allied services }\end{array}$ & 3169 & 8076 & 854 \\
\hline 10. Companhia Brasileira de Petróleo Ipiranga & Brazil & $\begin{array}{l}\text { Extraction of crude oil and natural gas } \\
\text { and allied services }\end{array}$ & 3106 & 1643 & $\ldots$ \\
\hline 11. Bimbo Industrial Group & Mexico & Manufacture of food products & 3026 & 63371 & 965 \\
\hline 12. Controladora Comercial Mexicana & Mexico & Wholesale trade & 2855 & 30093 & $\ldots$ \\
\hline 13. Grupo Votorantim & Brazil & Manufacture of non-metallic mineral products & 2815 & $\ldots$ & $\ldots$ \\
\hline 14. Vitro & Mexico & Glass manufacturing & 2720 & 32535 & 749 \\
\hline 15. Savia & Mexico & Manufacture of food products and drinks & 2664 & 18683 & 794 \\
\hline 16. Viação Aérea Rio-Grandense (VARIG) & Brazil & Air transportation & 2486 & 15600 & 170 \\
\hline 17. Grupo Desc & Mexico & Diversified (petrochemicals, vehicle parts) & 2444 & 20878 & 993 \\
\hline 18. Grupo Gigante & Mexico & Wholesale trade & 2414 & 33445 & 15 \\
\hline 19. Soriana organization & Mexico & Wholesale trade & 2169 & 29985 & $\ldots$ \\
\hline 20. Grupo Televisa & Mexico & Entertainment, television & 1889 & $\ldots$ & $\ldots$ \\
\hline
\end{tabular}

Source: Information Centre of the Unit on Investment and Corporate Strategies, ECLAC.

a Telcel exports.

Table 10 highlights three circumstances: firstly, the strong presence of Mexican firms, which have 13 places in the list, followed by five Brazilian firms, one Chilean one and just one Argentine one (the showing of Brazil, and even more so that of Argentina, is weak by comparison with the size of their economies); secondly, the continued predominance of the activities pointed to by Garrido and Peres (1998), to which may now be added telecommunications companies in Brazil and Mexico, large-scale retail trade, air transportation and activities linked to mining and the petroleum sector; and, lastly, the main exporters in the group are to be found in mining (CVRD), cement (Cemex), petroleum and petrochemicals (Alfa, Copec) and foods (Bimbo). In short, the latest information shows no change in the situation: companies specializing in mature-technology sectors, closely linked with the processing of natural resources.

Sectoral specialization in relatively homogeneous goods offering large economies of scale but produced by companies that are small compared to their main competitors lends a certain vulnerability to the competitive position of local private-sector companies. Protectionism meant that some of these sectors specialized in virtually untradable products, so that their performance depended entirely on the domestic market. As economies opened up, these sectors were increasingly confronted with competitors of global stature, whose power grew as their numbers shrank. As a result, local private-sector companies have lost the stability they enjoyed as leaders in these traditional sectors, and are now faced with the challenge of either growing or being absorbed by large international firms.

To complete this profile of local private-sector companies, it is necessary to describe the relationships they have established between their domestic markets and the international one. Their reaction to external competition, apart from the different strategies they followed to defend segments of their domestic markets, has been to branch out into non-traditional exports with the aim of extending their markets beyond the country, either within their historical regional ambits or in those they have developed as a result of integration, and even into the great markets of the industrialized countries.

Of the 41 domestic firms that belonged in 1996 to the top five in 19 industrial sectors, as examined in Peres (coord., 1998), 37 were exporters, although the sample does not record the value of their exports in all cases. 
Of the sectors where local companies predominated, exports to sales ratios were particularly high in agribusiness, cellulose and paper, steel and glass. Considering only the 24 local firms for which export data were given, the average ratio for the 19 industrial sectors was $23.6 \%$. This percentage, although almost double the equivalent 1994 figure (13.1\%), was much lower than that recorded for the foreign companies in the sample $(33.9 \%)$. This result was heavily influenced by the exports of automotive firms.

One group of local private-sector companies, generally the largest, internationalized their businesses more fully, exporting not only goods but capital as well. They have carried out direct investment abroad, whether by setting up new companies, taking over existing ones, or concluding strategic alliances or mergers.

This internationalization followed two models. On the one hand, some companies sought a regional presence as trade integration consolidated, as in the case of private-sector firms operating in Mercosur or within the framework of NAFTA. The largest investments in Mercosur were made by Enersis and the Compañía Manufacturera de Papeles y Cartones (CMPC) of Chile, Brazilian car part producers, and COFAP, in Argentina. In NAFTA, the largest investments were those made by Vitro (Mexico) in the United States. Some of the most noteworthy of these efforts, which seemed to promise a growing movement towards internationalization among local private-sector companies, were not followed through, either because the companies concerned were taken over by foreign investors, as Enersis was by Endesa España, or because they withdrew from some markets where they were unable to compete efficiently, one example being Vitro and its United States subsidiary Anchor Glass, which the Mexican company had to sell seven years after acquiring it in 1989. These groups did not achieve the scale and capabilities they needed to sustain their progress.

The other type of internationalization is more complex, and involves companies setting up a coherent system of subsidiaries in a number of countries in pursuit of a common strategy. These companies seek to become international, an aspiration that is heavily influenced by the form competition takes in their industries, examples being the manufacture of cement, steel tubes, bottled refreshments and beer. The most important cases in the region are those of Cementos Mexicanos (Cemex), which has investments in the United States, Spain, South and Central America and East Asia, and Techint, an Argentine firm which is a leader in the production of seamless tubes, and which has investments in Latin America and Europe.

The strategies of local private-sector companies can be classified as retreat, defence and offence, ${ }^{30}$ although the first of these will lead in the long run to the company going out of business, or to the original owners losing control. All three strategies are found among local private-sector firms although, because of their size, retreat tends to take the form of transfers of full ownership or majority control to external investors rather than outright closure, as happened with the Astra oil group in Argentina, the car part producer COFAP in Brazil and the two large Mexican cigarette manufacturers (Cigarros La Tabacalera Mexicana, CIGATAM and La Moderna).

Different methods have been used to defend domestic markets, the principal ones being pre-emptive investment (especially in the two largest economies), importing finished products to market them through local distribution networks, increasing and enhancing the focus on customer service (especially in the food industries), creating industrial and financial groups (in countries where the law allows this), ${ }^{31}$ and rent-seeking in the form of efforts to secure fiscal, commercial or sectoral promotion benefits which, although they count for less now than in the past, have not entirely disappeared, as is illustrated by the cases of the automotive industry in Argentina, Brazil and Mexico, the forestry industry in Chile and the support given to a variety of industrial sectors in Colombia.

Although it involves new diversified investments, one type of defensive strategy that has found favour is a move from industrial activities to modern non-tradable

\footnotetext{
${ }^{30}$ Defence, of course, is not a strategy that makes much sense in the long term. In the face of increased competitive pressure and the technological revolution now in progress, a defensive strategy can only be a stage on the way to retreat or offence. Experience also shows that there is no need for an initial defensive stage, as many of the largest companies adopted an offensive strategy right from the outset of the external debt crisis. Asset restructuring (mergers and acquisitions), investments abroad and linkage with the financial sector took place throughout the 1980s, although they were combined with strategies to defend domestic market share when the opening up process came into effect.

${ }^{31}$ Of the region's large and medium-sized countries, Chile stands out as the one with the lowest degree of formal linkage between industry and the banking system, this being a result of the crisis experienced in the early 1980s, although some of the country's industrial groups have clear links with banks. Again, in Chile, as in Brazil, pension funds (private-sector ones in the first case, those of the great State enterprises in the second) are holding a greater and greater proportion of the largest companies' share capital. This could open up new paths towards financially based conglomeration.
} 
services, such as telecommunications, or television and entertainment (table 10). The tendency to leave the industrial sectors is driven by the signals arising from trade liberalization and the macroeconomic policy of maintaining exchange rates that overvalue national currencies, which puts pressure on the profitability of tradable sectors. Meanwhile, opportunities to invest in non-tradable services, and the potential for benefiting from such investments, have been opened up by the deregulation of certain markets or the privileged access that some groups have been given to privatizations in the areas of telecommunications, electricity distribution and infrastructure in general.

It would seem that structural reform has not altogether done away with the rent-seeking behaviour of major business sectors since, while some nontradable services markets are fiercely contested among strong competitors, the conditions of this competition, and thus the profitability that is ultimately achieved, depend on State regulations and the different levels of access granted to the competitors.

Offensive strategies are more complex. Firstly, there is the strategy of growth through ever-increasing specialization around the essential core of the business, which is happening in some companies whose primary activity is the processing of natural resources, such as Klabin in Brazil, Alfa in Mexico and Pérez Companc and Bunge y Born in Argentina. This last is an extreme case, in that it is withdrawing from industrial activities to its original agricultural and trading base. Also belonging to this group are companies that have not increased what has traditionally been a high level of specialization, such as Cemex in Mexico and Grupo Matte in Chile.

A second strategy is growth through a moderate increase in diversification, which may combine vertical disintegration at the individual company level with greater vertical or horizontal integration at the group level as the result of participation in a few privatizations or in mergers or acquisitions involving other privatesector companies. In all cases, achieving potential synergies is the key objective when operations of this type are undertaken. Techint and Pescarmona in Argentina, Angelini in Chile, Suzano and Votorantim in Brazil, Santo Domingo (Bavaria) in Colombia and Pulsar in Mexico are examples of this moderate strategy.

Lastly, there is the strategy of growth through extreme diversification, largely by means of participation in numerous privatizations. These cases, which give rise to true conglomerates without obvious productive, commercial or even financial synergies, are often the result of a portfolio investment approach. The most striking cases are Sociedad Comercial del Plata (energy, construction and services) in Argentina, Vicunha (textiles, iron and steel and mining) in Brazil, and Carso (telephony, electrical conductors, tyres and restaurants) in Mexico. These conglomerates engage in very diverse activities, and the vigorous development they have achieved relatively recently has been based on strong links to the international capital market, the largest domestic banks and the political authority responsible for privatization decisions. Naturally, the financial risks and the benefits hoped for are high.

In each case, the strategies adopted depend on a complex set of factors. The sectoral factor is generally important, as competitiveness, and thus the ability to compete with imports in a liberalized economy, differs from sector to sector. The same is true of a sector's maturity, which is the result of a specific learning path along which greater or lesser progress may have been made, and of the range of promotional policies applying to it, as these, although they often go unrecognized, have been important in almost all the countries (petrochemicals in Argentina, the forestry industry in Chile and the automotive industry in Brazil and Mexico are some noteworthy examples). Nonetheless, the sectoral determinant is not enough in itself to account for corporate strategies.

The caution (or boldness) of corporate leaderships, as difficult as this is to define, is an important factor in explaining what strategy is ultimately adopted. Differences in management style -which are largely independent of systemic factors- would also seem to account for the varying levels of interest shown by different groups in relation to privatizations, ranging from extremely modest participation, or none at all, to an overwhelming presence both in the country of origin and elsewhere. Of course, management style and the quest for economic power are often inseparable in operational terms.

The above information, and the national case studies carried out for the region's three largest countries (Ferraz and Iootty, 2000, for Brazil; Garrido, 2000, for Mexico and Kulfas, 2000, for Argentina), reveal not only that local companies have lost ground to transnational ones, but that their pattern of specialization in production and international trade has retained its basic characteristic, with activities associated with the production or processing of natural resources predominating, but combined with a degree of participation in certain modern non-tradable sectors, such as telecommunications and the communications

CORPORATE COMPETITIVENESS IN LATIN AMERICA AND THE CARIBBEAN • MICHAEL MORTIMORE AND WILSON PERES 
media. If any shift is occurring, it would seem to be in the direction of yet greater predominance for primary activities, something that is most evident in the case of Argentina. It is for this reason that Kulfas (2000) has indicated that locally owned groups are going through a process of "primarization", the most striking example of which is the withdrawal of Bunge y Born from industrial activities. There are exceptions to the general trend, in the form of efforts by local companies to introduce more technology-intensive activities that are better placed to compete internationally. The most noteworthy examples are the production of aircraft by Embraer and the seed biotechnology activities of Savia (Grupo Pulsar, Mexico). These cases are a minority, however, and have not yet demonstrated the ability to

\section{IV}

\section{Conclusions}

The results of this research show that the region's international competitiveness has improved, but that progress has largely been confined to a few countries, sectors and firms. Increased heterogeneity in the ways the region participates in the international market, something that has been pointed out, for example, by Stallings and Peres (2000) and Katz (2000), has been one important result of the economic reforms that strengthened the role of market mechanisms in the allocation of resources, prompting greater specialization in the production structure and increased linkage of this with the outside world.

The different conditions under which the countries have engaged, through trade agreements, with different segments of the world economy have given rise, in conjunction with differences in cost advantages, to two styles of international trade participation. In Mexico and the Caribbean Basin, exports of manufactures assembled for the United States market predominate, the main concentrations being in the automotive, electronics and garment industries and most exporting being carried out by subsidiaries of efficiency-seeking transnational companies, generally within the framework of their IIPS. In South America, by contrast, natural resource production and processing activities prevail, although some more advanced manufactures, such as automobiles, are produced and traded within the region, especially within Mercosur. survive in the face of international competition. ${ }^{32}$ The activities that are most advanced and consolidated at the world level continue to be tied to natural resources; the most striking examples are the production of cement by Cemex (Mexico) and the construction of seamless tubes by Techint (Argentina).

Considering how local private-sector companies developed during the 1990s and how the dynamic of international trade and the sectoral and technological pattern of the region's participation in the international economy have been shifting, it has to be said that local private-sector companies, powerful agents in the region's economy though they still are, are increasingly being displaced from the first ranks of business.
Both sectoral specializations bring with them opportunities and difficulties. Specialization in assembly in maquila plants or free trade zones has enabled countries, including some very small and undeveloped ones, to increase their exports significantly, as a result of which they have been able to penetrate dynamic sectors of strong demand in the United States economy (which grew very vigorously during the 1990s). This specialization, however, has largely been confined to the lower value added sections of IIPS. Although there are signs of technological upgrading in Mexican maquila plants (so that reference is sometimes made to "third-generation maquila"), in the Caribbean and even in Mexico it is straightforward assembly activities that predominate. ${ }^{33}$ Even in cases

\footnotetext{
32 The activities of Pulsar in biotechnology and seed production began in 1997 and have gradually been tied in with the global technological research and development strategy of Monsanto (Garrido, 2000). The success of Embraer has been the result of many years of public policy support, which is coming up against increasing opposition in the context of current international trade regulations (Miranda, 2000).

${ }^{33}$ First-generation maquila industries require few or no workforce skills and give preference to volume over quality. Secondgeneration ones have certain requirements as regards quality and precision, use modern machinery, and generally need workers to have a secondary education. They employ modern forms of labour organization. Third-generation maquila industries mainly employ
} 
where more progress has been made, extension of the full package system to the Mexican apparel sector being an example, the activities that add most value (design and marketing) remain in the hands of head offices located in the United States.

The specialization of South America in sectors associated with natural resources is neither good nor bad in itself, and it has allowed countries such as Chile to increase their share of the world market. Analysis shows, however, that these sectors are not very dynamic in international trade (the dynamic defined by their low income elasticity of demand) and generally use mature technologies. The relatively small size of the leading local firms by comparison with their global competitors has meant that a number of them have withdrawn from the market, with their assets consequently being sold off to foreign investors. The strategy of these investors has generally been to explore new markets or sources of raw materials, by contrast with the efficiency-seeking strategy that prevails north of the Panama Canal.

The fact that progress with international competitiveness has largely been confined to certain economic agents, particularly large firms, be they transnational or locally owned, has been beneficial in terms of efficiency, to judge by the rising volume of exports and the share of these in the total. As these leaders have not drawn other agents in the local economy along in their wake, however, their strength has heightened the polarization of the production structure. Massive substitution of imports for locally produced inputs has made it possible to increase efficiency and to export, but has resulted in a breakdown of production chains. As a result the rest of the economy has lagged, so that Latin America has had export growth but not export-led growth (Stallings and Peres, 2000). In short, the opportunities opened up by globalization have not been capitalized upon.

The most negative part of the regional picture is the way progress with international competitiveness has been confined to just a few countries. This would seem to suggest that other factors, such as trade agreements and methods for attracting foreign investment, have played a more important role. In this respect, as in a number of others, the reforms have been unable to achieve the objectives that were set for them.

\section{Policy recommendations}

There is a need to consider what policy measures can best serve to overcome the shortcomings resulting from the fact that improvements in competitiveness have largely been confined to just a few countries, sectors and firms. There are four aspects of policy that seem to be of particular importance:

i) Given the decisive role played by transnational companies in the region's exports and competitiveness, there is a need for more effective policies to attract FDI, particularly new investments, rather than investment that goes into purchasing existing assets. Mortimore and Peres (1998) show that the countries use three types of mechanisms to compete for FDI: offering incentives

university-educated human resources for more knowledge-intensive activities. Buitelaar and Padilla (2000) identify a sprinkling of thirdgeneration maquila companies, in Mexico; most of that country's plants are second-generation. In Central America and the Caribbean, first- and second-generation plants coexist, with the latter gaining in importance. (essentially fiscal in nature), introducing norms that enhance competitiveness (the rule of law, market access through trade negotiations, labour and environmental standards) or creating assets (infrastructure and human resources). The first mechanism, although it may be effective in the short term, risks descending rapidly into a negative-sum game. The second type of instrument may have positive or negative effects, depending on the competition, when the regulations introduced improve on or weaken previous standards, something that is particularly harmful when there is a race to the bottom in labour or environmental standards. The creation of assets, lastly, while it is the most difficult mechanism to implement, is the most efficient one for national economies in the long term.

ii) Considering that the integration of transnational companies into IIPS has been the most effective mechanism for raising international competitiveness, attention should be turned to ways of increasing this integration in the countries where it already exists or

CORPORATE COMPETITIVENESS IN LATIN AMERICA AND THE CARIBBEAN • MICHAEL MORTIMORE AND WILSON PERES 
achieving it in the great majority that are particularly isolated from the most dynamic chains of world trade. The key role in this respect is played by trade negotiations to open up new markets that make it profitable to expand IIPS to new sectors and countries. Consideration should also be given to how progress can be made in incorporating segments of IIPS that add more value and how these can be tied in to the rest of the national economy. Although there have been cases of spontaneous progress in this direction, such as the move towards third-generation maquila, examples from international and regional experience show how efficient it is to develop policies to attract specific foreign companies or to increase the supply of inputs by local producers. By way of example, it is enough to allude to the measures taken by Costa Rica to attract investment from Intel in microprocessor production and the efficient programmes implemented in Singapore to develop local suppliers. Competition to attract investment by creating assets has contributed to this success, and efforts of this kind are particularly important for small countries that cannot expect the lure of their internal markets to produce good results.

iii) Closely related to the above is the question of linkage with worldwide knowledge networks. Specialization by locally owned groups in natural resource-related activities requires local technological research and development efforts that, because of the very nature of these resources, cannot be undertaken away from their physical context (Katz, 2000). These efforts -as has been shown by the biotechnology research of Grupo Pulsar, which has tended to become tied in with the research and development structure of Monsanto- are difficult to undertake efficiently in isolation from world technology developments. The instruments needed to achieve this technological impetus are well known from both regional and international experience; particular mention should be made of economies such as Japan, the Republic of Korea and Taiwan, whose domestic companies have made long-term efforts to improve their technological level, and have as a result succeeded, over time, in becoming transnationals.

iv) Given the relatively small size of domestic business groups by comparison with their global competitors, there is a need to support and strengthen their ability to create joint ventures and strategic alliances with those competitors, preferably under circumstances where they do not lose control of their assets. To this end, there is a need to develop corporate governance systems that make it attractive for foreign investors to participate in such alliances as minority partners. Experience shows that corporate governance systems can coexist very well with efforts to strengthen policies that defend competition and even, where necessary, with regulatory frameworks that promote it.

In summary, what this work proposes is the development and implementation of national strategies and active policies to supplement reform. Although some results are to be looked for from the spontaneous working of the market, international experience with efforts to attract and capitalize on foreign investment suggests that passive policies tend to result in greater benefits being generated for the investing companies than for the countries they invest in (Mortimore, 2000).

These policies are not easy to apply, given the weakness of the State in terms of human and financial resources. Although some instruments only involve changes to regulatory systems and cost little, making a country more attractive by creating assets and nurturing suppliers requires substantial resources. If applied successfully, this policy would allow more countries in the region to participate in the world market, and would even marginally improve the sectoral and technological quality of this participation.

Changing the pattern of specialization more radically by creating dynamic comparative advantages is a challenge that should be addressed by economic development studies. The conclusions of this work raise questions about this point. The relatively balanced triad -the State, large local firms and transnationals- on which industrialization and growth in Latin America were formerly based has been virtually destroyed by privatization and the relative decline of domestic firms (Reinhardt and Peres, 2000). The new pattern of economic leadership is still being defined, although everything points to it centring on transnational corporations. Experiences such as those of Singapore and Ireland show that this is viable and can be an efficient way of generating rapid growth. The main doubts still remaining, which it is beyond the scope of this work to address, have to do with the political repercussions of this model, the economic conditions that would make it viable in the region's less developed countries, and its appropriateness for the larger countries. 


\section{Bibliography}

Alcorta, L. and W. Peres (1998): Innovation systems and technological specialization in Latin America and the Caribbean, Research Policy, No. 26, Amsterdam, The Netherlands, North Holland.

Buitelaar, R. and R. Padilla (2000): Maquila, economic reforms and corporate strategies, World Development, vol. 28, No. 9, Oxford, U.K., Pergamon Press, Ltd.

Calderón, A.M., M. Mortimore and W. Peres (1996): Mexico: Foreign investment as a source of international competitiveness, in J. Dunning and R. Narula (eds.), Foreign Direct Investment and Governments: Catalysts for Economic Restructuring, London, Routledge.

Dussel, P.E. (1999): La economía de la polarización: teoría y evolución del cambio estructural de las manufacturas mexicanas, 1988-1996, Mexico City, Editorial Jus.

(2000): La inversión extranjera en México, Desarrollo productivo series, No. 80, Santiago, Chile, EClaC.

ECLAC (Economic Commission for Latin America and the Caribbean) (1998): Foreign Investment in Latin America and the Caribbean, 1998 Report, LC/G.2042-P, Santiago, Chile.

(2000): Foreign Investment in Latin America and the Caribbean, 1999 Report, LC/G.2061-P, Santiago, Chile.

(2001): Foreign Investment in Latin America and the Caribbean, 2000 Report, LC/G.2125-P, Santiago, Chile.

Ferraz, J.C. and M. Iootty (2000): Fusões e aquisições e internacionalização patrimonial no Brasil nos anos noventa, Rio de Janeiro, Rio de Janeiro Federal University, Institute of Industrial Economics.

Garrido, C. (2000): Fusiones y adquisiciones transfronterizas en México durante los noventa, Mexico City, Autonomous Metropolitan University.

Garrido, C. and W. Peres (1998): Las grandes empresas y grupos industriales latinoamericanos en los años noventa, in W. Peres (coord.), Grandes empresas y grupos industriales latinoamericanos, Mexico City, Siglo Veintiuno Editores.

Gereffi, G. (2000): The Transformation of the North American Apparel Industry: Is NAFTA a Curse or a Blessing?, Desarrollo productivo series, No. 84, Santiago, Chile, ECLAC.

Katz, J. (2000): Reformas estructurales, productividad y conducta tecnológica en América Latina, Santiago, Chile, Fondo de Cultura Económica (FCE)/ECLAC.

Krugman, P. (1994): The myth of Asia's miracle, Foreign Affairs, vol. 73, No. 6, Palm Coast, Florida, Council on Foreign Relations.

Kulfas, M. (2000): El impacto del proceso de fusiones y adquisiciones en la Argentina sobre el mapa de grandes empresas. Factores determinantes y transformaciones en el universo de las grandes empresas de capital local, Buenos Aires, ECLAC office in Buenos Aires.

Lall, S. (2000): Export Performance, Technological Upgrading and Foreign Direct Investment Strategies in the Asian Newly Industrializing Economies. With Special Reference to Singapore, Desarrollo productivo series, No. 88, Santiago, Chile, ECLAC.

Lall, S. and M. Mortimore (2000): Competitiveness, restructuring and FDI: An analytical framework, The Competitive Challenge: Transnational Corporations and Industrial Restructuring in Developing Countries, Geneva, United Nations.

Levitt, T. (1983): The globalization of markets, Harvard Business Review, vol. 83, No. 3, Boulder, Colorado, Harvard University.
Mendes de Paula, G., E. Pereira Silva and T.M. Couto da Silva (2000): Panorama do processo de fusões e aquisições na América Latina, 1990-99, Uberlândia, Brazil, Uberlândia Federal University, Institute of Economics.

Miranda, J.C. (2000): Abertura comercial, restruturação industrial e exportações brasileiras, Avaliação do potencial exportador das 500 maiores empresas industriais brasileiras, CLA/991671 Project, Rio de Janeiro.

Mortimore, M. (1998a): Getting a lift: Modernizing industry by way of Latin American integration schemes. The example of automobiles, Transnational Corporations, vol. 7, No. 2, Geneva, United Nations Conference on Trade and Development (UNCTAD).

(1998b): Corporate strategies and regional integration schemes in developing countries: The case of the NAFTA and Mercosur automobile industries, Science, Technology and Development, vol. 16, No. 2, Glasgow, U.K., University of Strathclyde, August.

(1998c): Chapter 2: United States, IDB (Inter-American Development Bank)/Institute for European-Latin American Relations, Foreign Direct Investment in Latin America: Perspectives of the Major Investors, Madrid, IDB/Institute for European-Latin American Relations.

(1998d): Mexico's TNC-centric industrialization process, in R. Kozul-Wright and R. Rowthorn (eds.), Transnational Corporations and the Global Economy, Helsinki, United Nations University/World Institute for Development Economic Research (WIDER).

(1999): Apparel-based industrialization in the Caribbean Basin: A threadbare garment?, CEPAL Review, No. 67, LC/G.2055-P, Santiago, Chile, ECLAC.

(2000): Corporate strategies for FDI in the context of the new economic model, World Development, vol. 28, No. 9 , Oxford, U.K., Pergamon Press, Ltd.

Mortimore, M., J.L. Bonifaz and J.L. Duarte de Oliveira (1997): La competitividad internacional: un CANálisis de las experiencias de Asia en desarrollo y América Latina, Desarrollo productivo series, No. 40, Santiago, Chile, ECLAC.

Mortimore, M., R. Buitelaar and J.L. Bonifaz (2000): México: un CANálisis de su competitividad internacional, Desarrollo productivo series, No. 62, Santiago, Chile, EClaC.

Mortimore, M. and W. Peres (1998): Empresas transnacionales e industrialización en economías pequeñas y abiertas: Costa Rica y República Dominicana, in G. Stumpo (ed.), Empresas transnacionales, procesos de reestructuración industrial y políticas económicas en América Latina, Buenos Aires, Alianza Editorial.

Oman, C. (1994): Globalisation and Regionalisation: The Challenge for Developing Countries, Paris, OECD (Organisation for Economic Co-operation and Development), Development Centre.

Peres, W. (coord.) (1998): Grandes empresas y grupos industriales latinoamericanos. Expansión y desafíos en la era de la apertura y la globalización, Mexico City, Siglo Veintiuno Editores.

Peres, W. and G. Stumpo (2000): Small and medium-sized manufacturing enterprises in Latin America and the Caribbean under the new economic model, World Development, vol. 28, No. 9, Oxford, U.K., Pergamon Press, Ltd. 
Reinhardt, N. and W. Peres (2000): Latin America's new economic model: Micro responses and economic restructuring, World Development, vol. 28, No. 9, Oxford, U.K., Pergamon Press, Ltd.

Stallings, B. and W. Peres (2000): Growth, Employment and Equity: The Impact of the Economic Reforms in Latin America and the Caribbean, Santiago, Chile, ECLAC.

Stumpo, G. (1998): Empresas transnacionales: procesos de reestructuración industrial y políticas económicas en América Latina, Santiago, Chile, ECLAC.

Sunkel, O. and M. Mortimore (1997): Integración transnacional y desintegración nacional en Latinoamérica y Asia: una revisión, in R. Urzúa (comp.), Cambio social y políticas públicas, Santiago, Chile, University of Chile, Centre for Public Policy Analysis.

Turner, L. and M. Hodges (1992): Global Shakeout, World Market Competition. The Challenges for Business and Government, London, Century Business.

UNCTAD (United Nations Conference on Trade and Development) (1993): World Investment Report 1993. Transnational Corporations and Integrated International Production, Geneva.

(2000): The Competitiveness Challenge: Transnational Corporations and Industrial Restructuring in Developing Countries, Geneva.

World Bank (1999): Global Development Finance, Washington, D.C. 